\title{
Peer Advisors for Veteran Education (PAVE): Implementing a sustainable peer support program for student veterans on college campuses
}

Michelle Kees, PhD; Brittany Risk, LMSW; Chrysta Meadowbrooke, MS; Timothy Nellett, BA; and Jane Spinner, MSW, MBA

\begin{abstract}
Student veterans have been attending college in greater numbers since the passing of the Post/911 GI Bill. Although similar to other nontraditional students, student veterans face unique transition challenges that can affect their pursuit of higher education. Many student veterans could benefit from dedicated programs to help them succeed in college, which in turn would enable them to secure employment in the civilian world. Facilitating the success of student veterans also makes wise use of the financial and institutional resources invested in their education. Peer support programs can help by providing an established community of other student veterans who can normalize transition experiences, offer social support, reduce stigma associated with help-seeking, and connect to useful services on and off campus. This paper describes the iterative development of a nationwide peer support program for student veterans, Peer Advisors for Education (PAVE), which uses trained peers to provide outreach, support, and linkage to resources to assist student veterans. Through a hybrid technology platform for training and program management, PAVE has been delivered on 40 college campuses nationwide and is well-positioned for larger scale national rollout.
\end{abstract}

\section{Keywords}

Peer support, military transition, peer program development, Post 9-11 GI Bill

\section{Student veterans on college campuses}

Campuses nationwide have experienced a vast increase in the number of veterans attending college in recent years, with over one million people using the Post-9/11 GI Bill during the four years after its inception in 2009 (U.S. Department of Veterans Affairs, 2013). The number of student veterans using these education benefits is expected to continue rising, given that the population of post-9/11 veterans is estimated to increase to more than five million by 2020 (U.S. Government Accountability Office, 2013). The need for programs that support student veterans and their unique circumstances will continue to grow as well.

Student veterans are in many ways nontraditional students (McBain, Kim, Cook, \& Snead, 2012). Older than their traditional classmates, they tend to have greater maturity gained through full-time work and other life experiences. Nontraditional students may feel stronger intrinsic motivation for learning and perseverance than traditional students (Bye, Pushkar, \& Conway, 2007). However, nontraditional students often have more responsibilities to manage outside of the classroom, such as working, parenting, and caregiving, which may affect their coursework 
and their engagement in the campus community (Kimmel, Gaylor, Grubbs, \& Hayes, 2012). Moreover, they also may need to refresh their academic skills and adjust to new educational technologies.

In addition, other challenges faced by student veterans can set them apart from both traditional and nontraditional students in significant ways. Veterans who transition from the military to college may find themselves in an unfamiliar and potentially isolating environment in which they have to learn to navigate the differences between military and academic cultures (Rumann \& Hamrick, 2010). Aside from the stresses common to college students, student veterans may also struggle with those found in the overall veteran population, such as economic uncertainty, changes in self-identity and relationships, physical injuries and related neurobehavioral symptoms, and mental health issues including depression and post-traumatic stress (Institute of Medicine, 2013; Tanielian \& Jaycox, 2008; Barry, Whiteman, \& MacDermid Wadsworth, 2014). The transition into college may be particularly difficult for female veterans, whose military and civilian experiences can differ markedly from those of their male colleagues (Burkhart \& Hogan, 2015; DiRamio, Jarvis, Iverson, Seher, \& Anderson, 2015).

\section{Leveraging peers}

Not all student veterans struggle in college, but among those who do, many hesitate to seek help due to concerns about stigma in both military and civilian contexts (Bonar, Bohnert, Walters, Ganoczy, \& Valenstein, 2015; Elliott, Gonzalez, \& Larsen, 2011). Peer programs may help reduce stigma and other barriers to care for veterans (Nelson, Abraham, Walters, Pfeiffer, \& Valenstein, 2014; Zinzow, Britt, McFadden, Burnette, \& Gillispie, 2012) and are a good fit on college campuses, where peer programs are commonly used to help students with adjustment to college life and persistence in their education (Shook \& Keup, 2012; Swenson, Nordstrom, \& Hiester, 2008).

Peer programs may help student veterans with the transition into college by connecting them with other student veterans who can offer information, resources, and a community of people who have had similar experiences and can offer social support (Steele, Salcedo, \& Coley, 2010; Whiteman, Barry, Mroczek, \& MacDermid Wadsworth, 2013). Social support helps protect against the effects of stressors (Cohen, 2004) and creates a sense of connectedness and engagement that are important to having a successful college experience (Kuh, Curce, Shoup, Kinzie, \& Gonyea, 2008; Hausmann, Schofield, \& Woods, 2007). Student veteran peer programs harness strengths inherent to the military ethos, including camaraderie, the buddy system, structure, and a sense of belonging. Student veterans already established on campus are also well suited to the task of helping other student veterans make the transition to academia; they can normalize the experience and provide local resources targeted to specific needs (DiRamio, Ackerman, \& Mitchell, 2008). Finally, peers who share common ground can help build trust and reduce stigma associated with seeking help (Mead, Hilton, \& Curtis, 2001; Solomon, 2004). Thus, peer programs such as Peer Advisors for Veteran Education (PAVE) can play a key role in promoting academic and personal success for student veterans on college campuses (Kees, Risk, Meadowbrooke, Spinner, \& Valenstein, in press). 


\section{Peer Advisors for Veteran Education (PAVE)}

Peer Advisors for Veteran Education (PAVE) is a peer support program that connects incoming student veterans with student veterans already on campus who have been trained as Peer Advisors. Peer Advisors assist other student veterans in navigating college life by providing a welcoming community and offering information and resources that can help address challenges they may encounter. PAVE has been developed in three phases and is currently implemented on 40 campuses across the country.

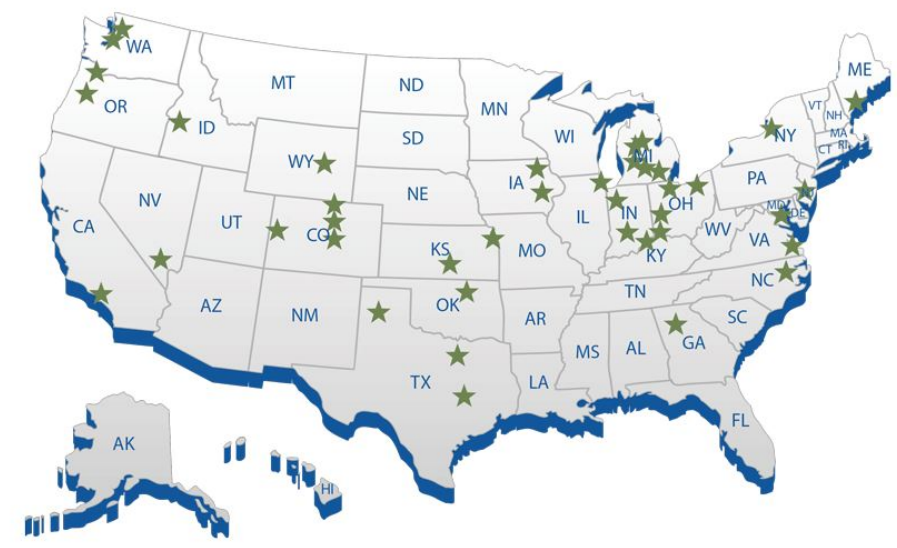

Figure 1. PAVE Partner Campuses in the United States. Reprinted with permission.

\section{Program model and program goals}

The main goals of the PAVE program are to: (a) ease the transition of student veterans from the military to college; (b) improve student veterans' sense of belonging on campus; (c) identify health concerns in a timely fashion and connect student veterans with appropriate resources; (d) create a feeling of community and a source of support among knowledgeable veteran peers; (e) increase student veteran retention rates; and (f) improve student veterans' academic performance.

The PAVE program model focuses on three pillars: outreach, support, and resource linkage.

- Outreach: Peer Advisors reach out to student veterans on a regular basis throughout the academic year. The purpose of this outreach is twofold: to inform student veterans about PAVE and other veteran-related services and events, and to check in consistently with students to see how things are going.

- Support: Through ongoing contact and shared activities, Peer Advisors create opportunities to discuss the student veteran experience, build trust, and ask if student veterans have any questions or concerns they could help resolve. Peer Advisors often establish camaraderie and credibility by providing information to address simpler needs first (e.g., orientation, parking, food, social events), which lays the groundwork for more personal conversations in the future.

- Resource linkage: Peer Advisors receive training about relevant on-campus and offcampus resources so that when a student veteran has a concern, a Peer Advisor can refer the student veteran to the best resource for their needs. Training includes the concept of a 
warm hand-off, in which the Peer Advisor creates a direct connection between the student veteran and someone at the referred resource, e.g., by calling ahead or going to the resource office together.

PAVE is not a counseling or treatment program; the PAVE Team uses a peer-based public health approach to foster credibility with student veterans and help overcome stigma around helpseeking. Decreasing stigma is of special relevance to student veterans for whom concerns about being weak or needing help may get in the way of asking for assistance, which is crucial to successfully transitioning to academic life after leaving the military.

\section{Iterative development of PAVE}

PAVE is part of the University of Michigan's Military Support Programs and Networks (MSPAN), a suite of programs addressing mental health and wellness for service members, veterans, and their families. PAVE emerged as a collaboration between the University of Michigan Depression Center and Department of Psychiatry and Student Veterans of America (SVA). The M-SPAN Team has an established history in developing and implementing peer programs in the military and veteran space. In 2008, M-SPAN worked collectively with the Michigan National Guard, colleagues at Michigan State University, and several Vietnam veterans to develop Buddy-to-Buddy, a community-integrated peer program for post-9/11 service members and veterans (Greden et al., 2010; Dalack et al., 2010). Recognizing the increasing numbers of veterans returning to civilian life and entering college, and noting the emerging issues with transition challenges, in 2012 the M-SPAN Team consulted with subject matter experts and reviewed recommended literature to further delineate issues and gaps in services specifically for student veterans. This exploration provided further evidence that stigma issues were a significant barrier to student veterans' willingness to seek assistance, and that there was a lack of awareness about available services and how to connect to them. It was hypothesized that using student veteran peers who had "been there" would resonate with incoming student veterans, and that these peers could help overcome stigma issues and facilitate linkage to needed resources on campus and in the community.

The development, implementation, and refinement of PAVE has occurred across three phases since 2012: (1) a pilot phase of early development and feasibility of PAVE at three Michigan colleges; (2) a second phase of expanding and refining PAVE with 13 national campus partners; and (3) a third phase of developing a technology platform for training and implementation to deliver PAVE at an additional 30 national campuses. The following sections of this paper will describe each phase of implementation and provide an overview of changes in the program model, key components of training in the model, and strengths and challenges encountered.

\section{Phase 1. Piloting PAVE}

In 2012, PAVE was launched as a one-tier peer-to-peer model using existing local SVA chapters to recruit and train Peer Advisors to work directly with student veterans. The program was initially piloted at three Michigan colleges, and the PAVE Team worked with the colleges' Veteran Services Coordinators (VSCs) to recruit Peer Advisors on campus to lead the program. The intent was for Peer Advisors to engage student veterans on campus, conduct outreach 
activities, provide peer support, and then connect student veterans with needed resources to help them succeed on campus.

Training Peer Advisors in the PAVE Model

Training in the PAVE model is a critical component of the program, and one that has evolved significantly over time. In the pilot implementation of PAVE, the PAVE Team went to each of the three campuses to conduct an in-person one-day training with Peer Advisors. During this phase, 17 Peer Advisors were trained on five key topic areas: (a) Peer Advisors' roles and responsibilities; (b) communication skills; (c) referrals and warm hand-offs; (d) recognizing mental health problems and managing mental health emergencies; and (e) self-care.

The Peer Advisor training built upon the strengths of student veterans as knowledgeable adult learners with lived experience and skills. PAVE trainers were culturally competent in working with military and veteran populations, either having been a member of the population themselves or having a professional background working with veterans. After the training, Peer Advisors were then supported by the PAVE Team via phone calls as they engaged with student veterans on their campus.

Strengths and Challenges

One of the key successes of the early PAVE pilot model was the good fit of using peers with student veterans. Student veterans were receptive to receiving help from their peers. Peer Advisors, also being student veterans, had a deep commitment to serving others and were invested in the program. The title of Peer Advisor was a deliberate and purposeful choice, due to the stigma commonly associated with the terms "peer mentor" and "peer counselor." This model of engagement continues to be an effective outreach strategy, normalizing receiving assistance.

Another success of the program was the offering to campuses of a set model, grounded in evidence-based approaches for both engaging college students and supporting veterans, along with a training curriculum and on-going logistics and implementation support from the PAVE Team. The pilot campuses wanted to do a peer support program for their student veterans, but did not know the key elements or strategies of implementing a program. PAVE filled that gap, and offered a tailored approach to fit their campus needs.

Several challenges emerged during the pilot phase of PAVE. First, it became clear that there were distinct functions that were necessary for program success. The Peer Advisors had to provide outreach and support to student veterans, and had to assume management of the program. Without clarity on who would perform these roles across the group of Peer Advisors at a school, they struggled to take on both functions. Furthermore, if one person in the Peer Advisor group was under-performing or not providing services within the scope of the role, it meant that the group had to figure out how to handle those issues, which were not easy tasks to execute among peers. Moreover, Peer Advisors found it difficult to identify and engage the broad population of student veterans. At the time of the pilot, student veterans were not routinely tracked or identifiable on many college campuses. This early pilot yielded important information about program enhancements to incorporate into the next phase of PAVE. 


\section{Phase 2. Expanding and refining PAVE}

In mid-2013, PAVE partnered with SVA at the national level to implement the program on additional campuses. SVA was a natural strategic partner since PAVE and SVA had the same primary goal: the academic and personal success of student veterans. Furthermore, SVA had established chapters on over 700 campuses with student veteran leaders as members, and these members could potentially serve as Peer Advisors. Both organizations agreed that the introduction of an additional and distinct leadership role was an important element to add to the model. Because taking on this role included a higher level of responsibility, student veterans on each campus who assumed these responsibilities would be offered paid stipends . Campuses sought varied approaches to paying team leaders, including internal discretionary funds, external grant support, or work-study through the campus or VA. This new role was designated the Peer Advisor Lead, or PAL. This role proved to be one of the most successful model shifts implemented. To more effectively distinguish their role and authority, the position was subsequently renamed Team Leader.

This phase of PAVE thus included a two-tiered system. Each campus had a paid Team Leader and a cadre of volunteer Peer Advisors who worked together with the VSC to implement the PAVE program. Team Leaders represented the on-campus program managers of PAVE and were essential in the day-to-day operations and success of the program. Peer Advisors were the core members of the PAVE Campus Teams and were responsible for direct outreach, support, and linkage to resources for student veterans. VSCs became integral to the success of PAVE and worked closely with Team Leaders and Peer Advisors, particularly in the area of recruiting and training team members. VSCs, who could provide continuity in PAVE from year to year, became the linchpin of the program. Furthermore, after further outreach and training, faculty leads enlisted to support the VSCs during times of transition, an innovation that evolved into the University Champion role.

Nationwide, 13 campuses participated in this phase of PAVE, reaching out to more than 2,100 student veterans between August 2013 and August 2016. The top three areas of student veteran concerns, as identified in logs submitted by Peer Advisors, included education (e.g., class registration, academic issues, study habits, tutoring, writing assistance), benefits and claims (e.g., GI Bill eligibility and enrollment, processing for VA healthcare claims), and mental health (e.g., anxiety, depression, general stress, posttraumatic stress, suicidality, substance use).

Training Campus Teams in the PAVE Model

A pivotal part of the program involved in-person trainings in the PAVE model with all members of the Campus Teams (Peer Advisors, Team Leaders, and later in implementation, the VSCs and University Champions) at each participating school. The PAVE Team conducted 56 trainings of Peer Advisors and Team Leaders, resulting in 262 individuals trained for those roles, as well as 2 trainings of VSCs and University Champions, with 17 individuals trained.

Peer Advisors. The curriculum for the one-day Peer Advisor training consisted of modules covering the history of the model; the scope of the program and team member roles; the core 
pillars of the program (outreach, support, and resource linkage) and best practice strategies for each; and skills training to help Peer Advisors meet their responsibilities as they assisted student veterans. For example, skills training included communication skills, team and community building, recognition of red flags, and role-plays to practice how to effectively refer student veterans to resources and what to do in the case of mental health emergencies. Self-care was its own module, with a strong emphasis placed on Peer Advisors taking good care of themselves so they could support others.

Team Leaders. Team Leaders also participated in the Peer Advisor training and received an additional one-day training designed to give them the necessary tools to plan, implement, and manage PAVE at their schools. The focused training included: (a) more extensive material about roles and responsibilities; (b) methods for successful outreach; (c) tips on building a resource network and making effective warm handoffs;(d) strategies for reducing stigma and barriers to care; (e)volunteer management; and (f) group facilitation skills. Feedback from Team Leaders early in this phase indicated the need for more concrete steps and assistance with mapping out the plan for PAVE implementation early in the semester. This led to the development of a key program tool, the Campus Work Plan, with a corresponding exercise added to the Team Leader trainings. PAVE trainers actively engaged Team Leaders in the development of a Work Plan customized to their campus, with detailed action steps for achieving program goals, including recruiting Peer Advisors, reaching out to student veterans, and building a network of veteran resources.

Veteran Services Coordinators and University Champions. Training materials for VSCs and University Champions changed to support their expanded role in overseeing the program on their campus. VSCs and University Champions attended a one-day in-person training in Ann Arbor, Michigan, with 4 campuses grouped in a spring 2014 training and 6 campuses in a fall 2014 training. These trainings gave VSCs and University Champions the opportunity to connect with the PAVE Team and to network with other PAVE campuses. The training focused primarily on understanding the PAVE model, key factors critical for model fidelity, and strategies for successful implementation. Additional topics included how to facilitate local trainings with Team Leaders and Peer Advisors, and demonstration of online communication tools used in the program (e.g., reporting suite and program management software).

\section{Implementation of PAVE}

After comprehensive training in the model, PAVE implementation began on the 13 campuses, with ongoing support from the PAVE Team provided through a combination of large group conference calls with Team Leaders and individual calls with Team Leaders or VSCs. The focus for these calls included reviewing essential program components, especially those related to the current implementation phase of the campus, and brainstorming strategies for success.

As campuses implemented PAVE, they asked Peer Advisors to document their efforts in the program. Peer Advisors tracked their interactions with student veterans through a secure webbased portal, noting information about the needs addressed with student veterans and the type of referrals provided. Team Leaders submitted online bi-weekly reports to the PAVE Team for review and discussion in the campus calls. Bi-weekly reports contained information about 
outreach activities; PAVE events and attendance; the pairing of student veterans with Peer Advisors; management and supervision of Peer Advisors; and connections made with faculty or other campus staff to talk about PAVE and its integration on campus.

\section{Strengths and Challenges}

PAVE campuses noted that they did not want to identify PAVE as a mental health program when promoting the program to student veterans, because of the stigma of mental health and the stereotype of student veterans as "broken heroes." This stigma presented a potential barrier to engagement in the program and ultimately threatened veterans seeking access to needed resources. In response, the program model quickly shifted to a public health approach, with an emphasis on identifying any needs of student veterans, be it financial, housing, legal, academic, health, mental health, or others.

Early in this phase of implementation, campuses were also facing a challenge in engaging student veterans with the program. To address both stigma and engagement, PAVE launched a match process for student veterans and Peer Advisors, the Opt-out model. In the Opt-out model, PAVE matched all incoming student veterans with a Peer Advisor, unless they chose to opt out of the program. PAVE then became a universal and routine offering to all student veterans on campus, as opposed to a targeted program for only the "struggling" students.

Implementing the Team Leader position was a critical factor in the success of a PAVE Campus Team. Team Leaders have created resource networks, obtained buy-in from campus stakeholders, and served as the cornerstone of student veteran leadership on their campus. For many student veterans, the Team Leader position is one they can relate to and understand, given the similar leadership structure of units within the military. The Team Leader provides the direct support, guidance, and focus Peer Advisors are accustomed to, with Peer Advisors benefitting from the peer support provided by their Team Leader much in the way that student veterans do from the Peer Advisors. The Team Leader also proved crucial to day-to-day implementation of PAVE on the campus. With a program heavily dependent on the energy, drive, and commitment of its personnel, an effective Team Leader had the potential to shape and elevate their PAVE Team into something new student veterans wanted to know more about, and participate in.

While the centralized logging portal implemented during this phase greatly improved the documentation of Peer Advisor efforts, Peer Advisors reported that they did not use the system consistently to record all of their outreach and interactions with student veterans. Some schools developed creative ways to increase logging, such as getting the Campus Team together at logging parties to eat pizza and back-log recent activities. It became clear, however, that another approach was needed in order to accurately and easily document the efforts of the program, and that perhaps logging could be done from smart phones or near real-time.

Succession and sustainability planning remained a challenge for campuses, even with the introduction of the Team Leader role. Strong leadership by active student veterans in a given year resulted in a successful program for that year, but efforts at training the "next generation" often fell short, and once student leaders graduated, new program leadership was not guaranteed. Schools found student veterans that had a positive experience with PAVE during their transition 
were more likely to volunteer and become Peer Advisors later on. PAVE staff encouraged the schools to incorporate these student veterans into the sustainability plan to replenish Peer Advisors each year.

The addition of 13 new schools and the expansion beyond Michigan drove home another sustainability challenge for the program: the resource costs incurred by having PAVE staff travel to individual schools to conduct in-person trainings for the Campus Teams. Scheduling also posed difficulties since most schools wanted to host trainings near the same time of year as they prepared for fall semester, resulting in a whirlwind of staff travel while also continuing to manage daily aspects of the program that required regular attention. One possible solution was to utilize a "train the trainer" model where VSCs would hold the responsibility for training the next cohort of Team Leaders and Peer Advisors. However, VSCs have many roles and competing priorities, with variable knowledge about the specifics of the PAVE program, so this too presented a challenge. It became clear that creating an online platform to make core training materials available at any time or location would benefit the program overall.

\section{Phase 3. Scaling PAVE with a technology platform}

The experience with the schools from the pilot and first phase of expansion confirmed that the enhanced PAVE model was effective in training Team Leaders and Peer Advisors to provide outreach, support, and linkage to needed resources for incoming student veterans at their schools. This led to planning how to scale the program, and whether it was possible to maintain the fidelity of the model and the high touch support to the schools, while increasing the number of PAVE campuses nationally. In this next phase of PAVE, a technology platform was developed and launched that allows for scalable training, tracking, and program management, while also expanding the program to an additional 30 campuses.

\section{Technology Platform}

Working with experts in technology and health communications, PAVE developed a multi-level platform for that includes three components. First, a Management Console allows VSCs and Team Leaders to manage the PAVE program on their campuses. It includes mechanisms to match student veterans with Peer Advisors, push out information to Peer Advisors electronically, and track trends and identify gaps in services. Secondly, a mobile-configured, web-based Tracking System enables Peer Advisors to more easily track their contact with student veterans.Lastly, an Online Training Course condenses the in-person training for Peer Advisors and Team Leaders to a set of interactive and engaging web-based modules. This integrated technology platform is self-sustaining and schools can use it as they continue to train new campus team members, and as new schools join the PAVE network.

Management Console. The Management Console includes functionality that allows VSCs and Team Leaders the ability to perform several key program tasks: securely upload student veteran information into the system and then match them to Peer Advisors and Team Leaders; invite Peer Advisors and Team Leaders to begin the online training; review Peer Advisor outreach efforts and interactions with student veterans; communicate with Peer Advisors on their work and suggest additional resources; upload and update an online resource guide compiled by their 
team; and complete bi-weekly reports that are sent to the PAVE Team to review. It also includes an embedded data collection tool that tracks usage of the system for Campus Team review.

Tracking System. The Tracking System operates on a secured mobile-configured website, and can be accessed easily through a smartphone or a computer. Through the Tracking System, Peer Advisors can log outreach and peer support activities, and can access a customizable resource directory for local and campus-specific resources. After each contact with a student veteran, Peer Advisors track their activity on the site, and answer a series of brief questions about their contact with the student veteran, including whether this was a first-time or repeat interaction, what the contact was about (e.g., student veteran needs), and what resource was provided to the student veteran. Past team leaders specifically requested a mobile-based application to reduce the barriers in tracking and logging program activity. This tracking information can evaluate impact and usage of the program and can inform individual campuses about their greatest student veteran needs and resources.

Online Training Site. The Online Training site includes a personalized welcome letter to each user to set the tone, and generate enthusiasm and buy-in. Peer Advisors can then access and complete the PAVE training modules (described below) at their own pace. In addition to the training modules, the site features a library of testimonial videos from Peer Advisors, Team Leaders, and VSCs speaking to their experience transitioning from military to college and the impact the PAVE program has had on their campus. The Training site also contains a toolkit, called the "PAVE Backpack", which allows easy access to program materials, tips sheets, and templates that will guide Team Leaders and Peer Advisors in successfully carrying out their roles.

Recruiting and Onboarding New Schools

In this phase of expansion, the PAVE Team worked closely with partners at SVA and the Department of Veterans Affairs to recruit and select campuses to participate in PAVE. Through a robust screening and interview process, the PAVE team selected 30 schools based on presence of success factors identified from the pilot launch. These factors included: (a) the number of student veterans on campus; (b) the number and diversity of existing veteran-friendly programs; (c) thecommitment of the VSC to the program; level of interest from student veteran leaders; endorsement from SVA or the VA; and ability to meet the expectations involved in implementing the program. the PAVE Team intentionally selected a representative mix of large public universities, private schools, and community colleges so as to garner data on specific challenges in each setting.

Upon selection as a PAVE partner campus, schools began the initial work necessary to launch the program in the fall of 2016, including completion of a Memorandum of Understanding (MOU) between the school and the University of Michigan. The PAVE team asked each campus to identify a 3-person Campus Team, comprised of the Team Leader, the VSC, and a University Champion. Teams then participated in a series of webinars designed to introduce them to the PAVE model and to start the pre-work for launching the program (e.g., Welcome to PAVE; Recruitment 101; Tech Walkthrough). 


\section{Hybrid Training Model}

In its first iterations, PAVE delivered trainings in-person over the course of multiple campus visits. This approach, while effective, was very time intensive and not conducive to large-scale dissemination. Thus, a hybrid training model was developed that includes a redesigned and more efficient in-person training for Campus Teams, an online training course with a series of interactive educational modules, and ongoing support from the PAVE Team to insure model fidelity.

In-person Training for Campus Teams. During August 2016, 128 representatives from 40 colleges and universities (12 original PAVE campuses and 28 new ones) attended the National Training Conference (NTC). The training was an updated and redesigned 2-day in-person training which included general sessions for the larger group, and also tracked training sessions for participants from each role category of the team. Tracked training sessions offered a unique opportunity for trainees to learn from each other and to form their own national peer group. The training also included protected time for the development of a Work Plan tailored for each school on what resources they needed to mobilize; how to recruit, enroll, and engage student veterans; and how best to manage Peer Advisors through team building.

Online Training Modules. As part of the process of converting the in-person training for Peer Advisors to a web-based platform, the PAVE team reviewed numerous modalities for optimized online engagement and learning preferences of our student veteran target audience. Six online modules for Peer Advisors were developed and released, with an additional module for Team Leaders (See Table 1 below). Each module ranges from 10 to 23 minutes in length, contains an animated video using cartoons, and an exercise that tests a Peer Advisor or Team Leader's ability to apply the material covered in the video. Peer Advisors and Team Leaders are required to complete the entire training before providing peer support to student veterans. 
Table 1.

PAVE Online Training Modules

\begin{tabular}{lll}
\hline Session & Module & Topics \\
\hline 1 & Welcome to PAVE & $\begin{array}{l}\text { Program model and overview; roles and } \\
\text { responsibilities; confidentiality }\end{array}$ \\
\hline 2 & $\begin{array}{l}\text { Outreach Strategies: How } \\
\text { to Connect with Student } \\
\text { Veterans }\end{array}$ & $\begin{array}{l}\text { Engagement theory; strategies to increase engagement; } \\
\text { challenges of non-response }\end{array}$ \\
\hline 3 & $\begin{array}{l}\text { Providing Support } \\
\text { Through Effective } \\
\text { Communication }\end{array}$ & $\begin{array}{l}\text { Communication skills; barriers to communication; } \\
\text { boundaries }\end{array}$ \\
\hline 5 & $\begin{array}{l}\text { Resource Linkage: How } \\
\text { to Make Successful } \\
\text { Referrals }\end{array}$ & $\begin{array}{l}\text { Building a resource network; creating a resource guide; } \\
\text { warm hand-offs }\end{array}$ \\
\hline $\begin{array}{l}\text { Mental Health Concerns: } \\
\text { Help to Look for, How to }\end{array}$ & $\begin{array}{l}\text { Identifying red flags; combating stigma; handling } \\
\text { emergencies }\end{array}$ \\
\hline 7 & $\begin{array}{l}\text { The Importance of Self- } \\
\text { Care }\end{array}$ & $\begin{array}{l}\text { Recognizing signs of burn-out; reaching out for } \\
\text { support; creating positive self-care strategies }\end{array}$ \\
\hline Leader
\end{tabular}

Support from the PAVE Team. The PAVE Team provided ongoing implementation support to each school, including the technical assistance necessary to ensure full and correct usage of mobile and web-based tools. Campus Teams had access to PAVE staff during business hours and on a scheduled basis via phone, text, online chat, and video conference functions. Individual check-in calls for Campus Teams allowed each team to discuss successes, challenges, and next steps, and to receive consultation and guidance from the PAVE Team. The primary areas of focus for these calls were implementation challenges, recruitment and outreach opportunities, and timeline targets for the program. Regular support calls with all Campus Teams increased peer support and collaboration across campuses. Additionally, the team offered webinars to continue to train campuses on the three components of the PAVE technology platform.

Strengths and Challenges

A key success of the latest PAVE model centers on the robust and diverse use of technology for campus management of the program, training team members, and tracking activity of the Peer Advisors. The technology platform has had a significant impact on the number of schools that can be on-boarded to the program, and therefore the number of student veterans who can be served. In the first eight months of implementation of this phase of PAVE, PAVE Campus Teams reached more than 5000 student veterans. Planners also designed this platform to be selfsustaining such that schools can continue to use all components of the technology in ongoing implementation of PAVE, with recruitment and training of new Peer Advisors, and enrolling of new cohorts of student veterans in subsequent semesters. 
The Management Console allows Team Leaders and VSC to track and manage all aspects of the program from a central shared platform, from the point of matching student veterans with Peer Advisors, to tracking Peer Advisor activity, and building a resource database for the program. Training of Campus Teams has also become more standardized and more efficient with the development on the online training modules. In the first six weeks of fall 2016, 318 Peer Advisors and Team Leaders completed the online training. More Peer Advisors completed training online in six weeks than were trained in-person over the course of 3 years. Lastly, the tracking system makes it easy for Peer Advisors to track their activity in the program and to share this information with their Team Leaders and the PAVE Team.

While most partner campuses have had great success implementing PAVE, the first year is time intensive and sometimes challenging for schools. The length of time that it takes to embed a PAVE team fully on a campus averages about three semesters, and the need for a strong Campus Team is imperative. Several factors seem to result in difficulties in implementation, including staff turnover at the VSC or University Champion level, lack of administration buy-in, ebbs and flows in participation by Team Leaders and Peer Advisors, interpersonal conflict among Campus Teams, and inability to secure ongoing funding for the Team Leader role. Some schools have been unable to implement PAVE effectively, due to these challenges.

The PAVE Team provides high levels of support continually after program launch to assist schools through these challenges in hopes of ultimate success. Individualized support is provided to each campus along with the opportunity to connect with other schools who are also implementing the program. While training and program management tools are beneficial and needed, ongoing technical assistance and support from the PAVE Team is also critical. Campus Teams have also recognized the value of the PAVE Team's guidance and expertise in problem solving throughout program implementation.

\section{Next Steps}

As described, PAVE has benefited from a multifaceted and iterative development process responsive to real-world feedback from partner campuses as they have implemented the program. The final product is a turnkey peer support program for college veterans that has been field-tested and found to be effective. It connects with student veterans, providing peer support, and linking students to needed resources on campus and in the community (Kees et al., in press). The next steps for PAVE go in two directions: 1) increasing the PAVE network with more partner campuses; and 2) developing and disseminating online modules specifically for student veterans participating in PAVE.

\section{PAVE Network Growth}

The web-based platform for disseminating PAVE is virtually limitless, capable of supporting a vast rollout and scaling of the program at the national level. Increasing the network of PAVE schools is a priority next step, with several potential directions under consideration. One approach is to replicate the most recent expansion efforts with the release of a new Request for Applications and engaging campuses around the country to launch PAVE. Another possibility is to focus on regional expansion by selecting a specific state(s) and identifying a cohort of schools 
in that area to implement PAVE. A third approach shifts the lens to community colleges, which are a common route for veterans making the transition to 4-year universities.

Data from the U.S. Department of Education indicate that $43 \%$ of military students attend community colleges (Radford, 2011). Six of our PAVE campuses have been community colleges and present unique challenges in implementing peer support programs because of factors often inherent to community colleges (e.g., more likely to be commuter schools, with short-term attendance, and challenges in establishing a community). The PAVE Team has learned some important lessons in collaborating with community colleges, and is now in a better position to offer a successful peer program to this unique group of student veterans.

Each of these three expansion approaches require funding to maintain fidelity of the model, including attendance at the initial PAVE training and the ongoing support and technical assistance provided by the PAVE Team. Funding models under exploration include a fee-forservice model with schools, foundation grants, donor or corporate gifts, or research grants examining the longitudinal impact of the program.

Online Modules for Student Veterans

To date, the PAVE program focuses on training and support of the Campus Teams (Peer Advisors, Team Leaders, VSCs, and University Champions), with no direct engagement or materials for student veterans on PAVE campuses. Campus Teams have specifically requested additional resources to share with their student veterans. To this end, the PAVE Team recently piloted an in-person "Success Course” for student veterans at two campuses. Participants received the course very well, and yet, dissemination of the course as an in-person offering presents challenges for costs and sustainability. A next step for PAVE is to convert key components from this Success Course into online modules using the same interactive approach currently utilized in the online training for Peer Advisors and Team Leaders. The PAVE team will develop the existing materials for the Success Course in three areas: Personal Growth and Development; Academic Success; and Career Preparation. Peer Advisors will be well in position to share this information directly with student veterans on their campuses, and the team expects them to have a positive impact on the academic and personal success of those students.

\section{Conclusion}

Veterans are returning to college campuses at the highest rate since World War II, with a taxpayer investment in their education benefits reaching more than $\$ 20$ billion since 2009 (U.S. Department of Veterans Affairs, 2016). According to research conducted by the PAVE Team's partner organization, SVA, more than 347,00 student veterans have earned degrees and certifications using the Post-9/11 GI Bill since 2009 (Cate, Lyon, Schmeling, \& Bogue, 2017). In 10 years, more than 1.4 million student veterans will have earned college degrees. Moreover, student veterans are doing well in school. Student veterans have a higher GPA than the national average (3.35 vs. 2.94), and have a higher graduation rate than similar non-traditional peers (Student Veterans of America, 2017). 
The best service we as a country can give to those who have served is to help them succeed. PAVE is a well-designed, field-tested, peer-to-peer approach that offers a strategic solution for institutions to better support the student veteran population, while also increasing student veterans' connection to campus, decreasing stigma around help seeking, and providing linkage to needed resources. PAVE is a promising model for supporting student veterans on college campuses as they transition from the military to academia, and ultimately to successful employment.

\section{Authors' Note}

Initial funding for the design and piloting of PAVE was provided by the Welcome Back Veterans initiative, which includes the Robert R. McCormick Foundation and Major League Baseball Charities. Phase 2 and 3 of further iterative development and national scaling received support from the Bristol-Myers Squibb Foundation. In Phase 2, Student Veterans of America also received funding from the Bob Woodruff Foundation and the Wounded Warrior Project to enhance aspects of the training model. Additionally, the Robert R. McCormick Foundation supported the development and implementation of the in-person course for student veterans. 


\section{References}

Barry, A. E., Whiteman, S. D., \& MacDermid Wadsworth, S. (2014). Student service members/veterans in higher education: A systematic review. Journal of Student Affairs Research and Practice, 51(1), 30-42. https://doi.org/10.1515/jsarp-2014-0003

Bonar, E. E., Bohnert, K. M., Walters, H. M., Ganoczy, D., \& Valenstein, M. (2015). Student and nonstudent National Guard service members/veterans and their use of services for mental health symptoms. Journal of American College Health, 63(7) 437-446.

https://doi.org/10.1080/07448481.2014.975718

Burkhart, L., \& Hogan, N. (2015) Being a female veteran: A grounded theory of coping with transitions. Social Work in Mental Health, 13(2), 108-127.

https://doi.org/10.1080/15332985.2013.870102

Bye, D., Pushkar, D., \& Conway, M. (2007). Motivation, interest, and positive affect in traditional and nontraditional undergraduate students. Adult Education Quarterly, 57(2), 141158. https://doi.org/10.1177/0741713606294235

Cate, C. A., Lyon, J. S., Schmeling, J., \& Bogue, B. Y. (2017). National Veteran Education Success Tracker: A report on the academic success of student veterans using the Post-9/11 GI Bill. Washington, DC: Student Veterans of America. Retrieved from http://nvest.studentveterans.org/wp-content/uploads/2017/03/NVEST-Report_FINAL.pdf

Cohen, S. (2004). Social relationships and health. American Psychologist, 59(8), 676-685. https://doi.org/10.1037/0003-066x.59.8.676

Dalack, G. W., et al. (2010). Working together to meet the needs of Army National Guard soldiers: An academic-military partnership. Psychiatric Services, 61(11), 1069-1071. https://doi.org/10.1176/appi.ps.61.11.1069

DiRamio, D., Ackerman, R., \& Mitchell, R. L. (2008). From combat to campus: Voices of student-veterans. Journal of Student Affairs Research and Practice, 45(1), 73-102. https://doi.org/10.2202/1949-6605.1908

DiRamio, D., Jarvis, K., Iverson, S., Seher, C., \& Anderson, R. (2015). Out from the shadows: Female student veterans and help-seeking. College Student Journal, 49(1), 49-68.

Elliott, M., Gonzalez, C., \& Larsen, B. (2011). U.S. military veterans transition to college: Combat, PTSD, and alienation on campus. Journal of Student Affairs Research and Practice, 48(3), 279-296. https://doi.org/10.2202/1949-6605.6293

Greden, J. F., Valenstein, M., Spinner, J., Blow, A., Gorman, L. A., Dalack, G. W., Marcus, S., \& Kees, M. (2010). Buddy-to-Buddy, a citizen soldier peer support program to counteract stigma, PTSD, depression, and suicide. Annals of the New York Academy of Sciences, 1208, 9097. https://doi.org/10.1111/j.1749-6632.2010.05719.x 
Hausmann, L. M., Schofield, J., \& Woods, R. (2007). Sense of belonging as a predictor of intentions to persist among African American and white first-year college students. Research in Higher Education, 48(7), 803-839. https://doi.org/10.1007/s11162-007-9052-9

Institute of Medicine. (2013, March). Returning home from Iraq and Afghanistan: Assessment of readjustment needs of veterans, service members, and their families. Washington, DC: The National Academies Press. Retrieved from http://www.nationalacademies.org/hmd/Reports/2013/Returning-Home-from-Iraq-andAfghanistan.aspx

Kees, M., Risk, B., Meadowbrooke, C., Spinner, J. L., \& Valenstein, M. (in press). Navigating success: Peer support for student veterans. In D. DiRamio (Ed.), What's next for student veterans? Moving from transition to academic success. Columbia, SC: National Resource Center for the First-Year Experience and Students in Transition.

Kimmel, S. B., Gaylor, K. P., Grubbs, M. R., \& Hayes, J. B. (2012). Good times to hard times: An examination of adult learners' enrollment from 2004-2010. Journal of Behavioral and Applied Management, 14(1), 18-38. Retrieved from http://search.proquest.com/docview/1082324507?pq-origsite=360link\&accountid=14667

Kuh, G. D., Curce, T. M., Shoup, R., Kinzie, J., \& Gonyea, R. M. (2008). Unmasking the effects of student engagement on first-year college grades and persistence. The Journal of Higher Education, 79(5), 540-563. https://doi.org/10.1353/jhe.0.0019

McBain, L., Kim, Y. M., Cook, B. J., \& Snead, K. M. (2012). From soldier to student II: Assessing campus programs for veterans and service members. Washington, DC: American Council on Education. Retrieved from http://www.acenet.edu/news-room/Documents/FromSoldier-to-Student-II-Assessing-Campus-Programs.pdf

Mead, S., Hilton, D., \& Curtis, L. (2001). Peer support: A theoretical perspective. Psychiatric Rehabilitation Journal, 25(2), 134-141. https://doi.org/10.1037/h0095032

Nelson, C. B., Abraham, K. M., Walters, H., Pfeiffer, P. N., \& Valenstein, M. (2014). Integration of peer support and computer-based CBT for veterans with depression. Computers in Human Behavior, 31, 57-64. https://doi.org/10.1016/j.chb.2013.10.012

Radford, A. W. (2011). Military service members and veterans: A profile of those enrolled in undergraduate and graduate education in 2007-2008 (Report No. 2000-163). Washington, DC: National Center for Education Statistics. Retrieved from http://nces.ed.gov/pubs2011/2011163.pdf

Rumann, C. B., \& Hamrick, F. A. (2010). Student veterans in transition: Re-enrolling after war zone deployments. The Journal of Higher Education, 81(4), 431-458.

https://doi.org/10.1353/jhe.0.0103 
Shook, J. L., \& Keup, J. R. (2012). The benefits of peer leader programs: An overview from the literature. New Directions for Higher Education, 157, 5-16. https://doi.org/10.1002/he.20002

Solomon, P. (2004). Peer support/peer provided services: Underlying processes, benefits, and critical ingredients. Psychiatric Rehabilitation Journal, 27(4), 392-401.

https://doi.org/10.2975/27.2004.392.401

Steele, J. L., Salcedo, N., \& Coley, J. (2010). Service members in school: Military veterans' experiences using the Post-9/11 GI Bill and pursuing postsecondary education. Santa Monica, CA: RAND Corporation. Retrieved from

http://www.rand.org/content/dam/rand/pubs/monographs/2011/RAND_MG1083.pdf

Student Veterans of America. (2017). Research brief: Profile of the contemporary student veteran. Washington, DC: Student Veterans of America. Retrieved from http://nvest.studentveterans.org/wp-content/uploads/2017/04/Profiles-of-a-ContemporaryStudent-Veteran.pdf

Swenson, L. M., Nordstrom, A., \& Hiester, M. (2008). The role of peer relationships in adjustment to college. Journal of College Student Development, 49(6), 551-567.

https://doi.org/10.1353/csd.0.0038

Tanielian, T., \& Jaycox, L. H. (Eds.) (2008). Invisible wounds of war: Psychological and cognitive injuries, their consequences, and services to assist recovery. Santa Monica, CA: RAND Corporation. Retrieved from http://www.rand.org/content/dam/rand/pubs/monographs/2008/RAND_MG720.pdf

U.S. Department of Veterans Affairs. (2013, November). One million now benefit from Post9/11 GI Bill [press release]. Office of Public and Intergovernmental Affairs, U.S. Department of Veterans Affairs. Retrieved from http://www.va.gov/opa/pressrel/pressrelease.cfm?id=2490

U.S. Department of Veterans Affairs. (2016, August 8). VA and the Post 9/11 GI Bill. Retrieved from https://www.va.gov/opa/issues/post_911_gibill.asp

U.S. Government Accountability Office. (2013, July). VA education benefits: Student characteristics and outcomes vary across schools (Publication No. GAO-13-567). Retrieved from http://www.gao.gov/assets/660/656204.pdf

Whiteman, S. D., Barry, A. E., Mroczek, D. K., \& MacDermid Wadsworth, S. (2013). The development and implications of peer emotional support for student service members/veterans and civilian college students. Journal of Counseling Psychology, 60(2), 265-278.

https://doi.org/10.1037/a0031650

Zinzow, H. M., Britt, T. W., McFadden, A. C., Burnette, C. M., \& Gillispie, S. (2012). Connecting active duty and returning veterans to mental health treatment: Interventions and treatment adaptations that may reduce barriers to care. Clinical Psychology Review, 32(8), 741753. https://doi.org/10.1016/j.cpr.2012.09.002 


\section{Author information}

* Michelle Kees, PhD is an Associate Professor in Child and Adolescent Psychiatry at the University of Michigan, has dual Clinical and Research Without Compensation appointments at the Ann Arbor Veterans Affairs Medical Center, and is a lead investigator with Military Support Programs and Networks (M-SPAN). Dr. Kees is the Principal Investigator for PAVE (Peer Advisors for Veteran Education). She is also the Principal Investigator of HomeFront Strong, a resiliency intervention for military spouses and children.

Michelle Kees, PhD

Associate Professor, Department of Psychiatry

Principal Investigator, M-SPAN (Military Support Programs and Networks)

University of Michigan

2025 Traverwood, Suite C

Ann Arbor, MI 48105

Email: mkees@umich.edu

Web: http://m-span.org/

Brittany Risk, LMSW is the Program Manager for PAVE. She coordinates and oversees all aspects of the implementation of the PAVE Program. Prior to her work with M-SPAN, Ms. Risk was a project manager at the Department of Veterans Affairs on grants that focused on veteran mental health, substance abuse, and suicide.

Brittany Risk, LMSW

Program Manager

Peer Advisors for Veteran Education (PAVE)

University of Michigan

2025 Traverwood, Suite C

Ann Arbor, MI 48105

Email: konarzbr@umich.edu

Web: http://paveoncampus.org/

Chrysta Meadowbrooke, MS is the Research Specialist for M-SPAN, working on research and evaluation for PAVE and other military and veteran-focused programs. She has several years of experience on community-based health and clinical projects, performing both qualitative and quantitative data collection and analysis.

Chrysta Meadowbrooke, MS

Research Specialist, M-SPAN (Military Support Programs and Networks)

University of Michigan

2025 Traverwood, Suite C

Ann Arbor, MI 48105

Email: cmeadow@umich.edu

Web: http://m-span.org/ 
Timothy Nellett, BA is the Program Coordinator for PAVE. He oversees the day-to-day operations of the PAVE Program, such as onboarding and supporting current partner campus. Mr. Nellett served in the United State Marine Corps for four years, deploying to Iraq and Afghanistan with the $1^{\text {st }}$ Battalion 6 Marine Regiment in support of Operations Iraqi Freedom and Enduring Freedom.

Timothy Nellett, BA

Program Coordinator

Peer Advisors for Veteran Education (PAVE)

University of Michigan

2025 Traverwood, Suite C

Ann Arbor, MI 48105

Email: tnellett@umich.edu

Web: http://paveoncampus.org/

Jane Spinner, MSW, MBA is Project Officer for Strategic Initiatives at the University of Michigan Depression Center and Department of Psychiatry. Ms. Spinner oversees the design, development, and implementation of major projects and initiatives that address the mental health needs of special populations, including the portfolio of military and veteran-focused programs at M-SPAN.

Jane Spinner, MSW, MBA

Project Officer for Strategic Initiatives

Project Director, M-SPAN (Military Support Programs and Networks)

University of Michigan

2025 Traverwood, Suite C

Ann Arbor, MI 48105

Email: jspinner@umich.edu

Web: http://m-span.org/

*Corresponding author 